\title{
Myanmar - Misrepresenting a Development Problem as a Religious Conflict
}

\author{
Kalinga Seneviratne \\ Former Head of Research, Asian Media Information and Communication Center (AMIC), Singapore \\ Corresponding author: kalingasen@gmail.com
}

Received: 12 Sept., 2020

Revised: 27 Nov., 2020

Accepted: 06 Dec., 2020

\begin{abstract}
In recent years, before the February 2021 coup in Myanmar, the international media narrative on Myanmar has been focused on the "Rohingya" issue presenting it as a case of a helpless Muslim minority being repressed by a powerful Buddhist majority. A so-called religious conflict has been overplayed, and the socio-economic conditions and development issues that have given rise to this conflict are being ignored. Myanmar's attempted transition to democracy was hamstrung by a development dilemma that did not include merely minorities, but a major section of the rural Buddhist majority. This paper discusses the socio-economics of the Rohingya issue, and how geopolitical issues contribute to the conflict. The paper argues that a new mindful communication strategy is needed to report Myanmar's development problems in a more balanced fashion.
\end{abstract}

Keywords: Socio-economic Development, Adversary Journalism, Mindful Communication, Fake News, Repressed Minority

\section{The Problem}

In recent years, the international media narrative had often tried to paint a simple black and white picture of Buddhist "nationalism" on one hand battling Rohingya "terrorism" threat on the other. But, the biggest obstacle to Myanmar's transition to democracy is the under-development of rural areas where various ethnic and religious minorities live alongside majority Buddhists.

Giving the 43rd Singapore Lecture in August 2018 (Suu Kyi, 2018), Myanmar's leader Aung San Suu Kyi argued that religious or ethnic conflicts cannot be solved before a clear socio-economic path is implemented. "Our people yearn for peace and security, for an end to unrest and strife, for material and emotional security, for a chance to contemplate the future of their children with tranquility," said Suu Ki adding that the right direction for her country "is the one that will lead to an improvement in the quality of life for our people".

Throughout her hour-long address to Singapore's political, business, and academic elites, she emphasized that the challenge of democratizing Myanmar was rooted in socio-economic development, and religious conflicts and terrorism could be solved by a proper development path encompassing all communities which the international community

How to cite this article: Seneviratne, K. (2020). Myanmar Misrepresenting a Development Problem as a Religious Conflict. Int. J. Peace, Edu. Dev., 8(02): 91-99.

Source of Support: None; Conflict of Interest: None (2) 9 
need to support by investing in Myanmar to assist the empowerment of its people.

She identified 5 goals for Myanmar's Sustainable Development Plan, which could also be seen as a roadmap for the transition to democracy. Three pillars support these 5 goals. Goal 1 is Peace, National Reconciliation, Security, and Good Governance and Goal 2 is Economic Stability and Strengthened Macroeconomic Management. These rest on the pillar of Peace and Stability. Goal 3 is Job Creation and Private Sector-led Growth, held up by the pillar of Prosperity and Partnership. The third pillar, People and Planet, supports Goal 4, Human Resources and Social Development for $21^{\text {st }}$ Century Society, and Goal 5, Natural Resources and the Environment for Prosperity of the Nation.

"A sound base for peace and stability has to be broad and comprehensive," argues SuuKyi, adding, "addressing destabilizing issues in Rakhine State was a fundamental part of building our Pillar one". Thus, she acknowledges that the terrorism and destabilizing activities in Rankine state, which she described as a "security challenge", is a barrier to achieve these goals. "The risk of intercommunal violence ... is a threat that could have grave consequences not just for Myanmar but also for other countries in our region and beyond. Terrorism should not be condoned in any form for any reason," she added.

At the time of writing, though Myanmar's path towards democratization seems to have taken a step backward with the military coup of 1st February 2021, yet, the issues addressed in this paper will still be relevant in mapping Myanmar's future development path and paving the path for peaceful co-existence in a country that is home to some 135 ethnic groups (Al Jazeera, 2017).

\section{Visiting the Problem}

The researcher studied the problem through interviews of several persons who were in the thick of happenings. He also observed multireligious coexistence and practice of own religion in an area of Yangon where co-exists people of all religious groups. In searching media portrayal from Western countries and Asian countries, topical analysis was resorted. Findings are presented in a descriptive manner.

\section{Religious Conflicts Overplayed}

Myanmar is a complicated country, and many nuances are involved that are ignored or misrepresented by the mainstream international media narrative.

In December 2018, I spent 10 days in Yangon talking to Buddhist scholars and media practitioners about their view of the conflict between the Rohingya Muslim minority and their government, and about the international media coverage of their country. The overwhelming message I got was that the international (meaning Western) media was "unfair" to Myanmar (Seneviratne, 2019). They feel the Buddhists are misrepresented in overseas media. They may have a point, as people overseas hardly hear about what I saw in Yangon.

When I checked into a hotel at 10.00 pm in Central Yangon near the iconic Sule Pagoda, seeing a lot of South Asian Muslims around the place, I asked the hotel reception if it was safe to walk up the road to get some dinner. The receptionist laughed and said: "It is very safe here, sir." For the next 10 days, I lived in the heart of a Muslim Bengali/ Indian community. I walked around the place late at night and early mornings and found that it is a very peaceful community where the Muslims, Buddhists, Hindus, and Christians interact well.

Sule Pagoda is right next to the Bengali Sunni Central Mosque. There are four Christian cathedrals (of course built by the British colonisers), two Hindu temples, and numerous small Buddhist temples. The Buddhist nuns chanted Pali sutras for about two hours on Saturday night and these were broadcast through a loudspeaker right into the Muslim community - without any problems whatsoever; perhaps both Muslims and Buddhists consider it a blessing. Mosques broadcast their call to prayer on the loudspeakers (no problem for Buddhists either); Hindus ring their temple bells and play the drums for morning prayer; Christians have decorated the streets for Christmas and were having a huge fair 
and a Christian concert on a stage erected in a park next to a church and right in front of the Sule Pagoda.

No one had a problem with the Buddhists, Hindus, and Muslims joining in the Christmas festivities. The only problem I noted was a group of Christians led by a White Australian missionary distributing leaflets in Burmese about Jesus right opposite the Sule Pagoda. He told me, "We want the Burmese to know about the peaceful message of Jesus". But I asked myself, "Are they trying to create conflict on such a festive occasion?"

International media often focus on a firebrand monk Wirathu from Mandala, who heads a Buddhist nationalist group called Ma Ba Tha. The Time magazine, in a cover story published on 1st July 2013 with a picture of the monk labeled him "The Face of Buddhist terrorism". It said:

It seems a peaceful scene, but Wirathu's message crackles with hate. "Now is not the time for calm," the monk intones, as he spends 90 minutes describing the many ways in which he detests the minority Muslims in this Buddhist-majority land. "Now is the time to rise up, to make your blood boil." Buddhist blood is boiling in Burma, also known as Myanmar - and plenty of Muslim blood is being spilled. Over the past year, Buddhist mobs have targeted members of the minority faith, and incendiary rhetoric from Wirathu - he goes by one name - and other hard-line monks are fanning the flames of religious chauvinism (Time magazine, 1 July 2013). ${ }^{1}$

The above quotes angered many Buddhists across Asia. It also triggered a debate within Buddhist communities about the role of the sangha (order of monks) in political matters. The article by Hanna Beechwas very critical of the 46-year-old Buddhist monk who attracts a huge following in Myanmar where close to 90 percent of the people claim to be Buddhist. The writer described the "radical monk" as someone who sees Muslims - who make up at least 5 percent of Myanmar's estimated 60 million people - as a threat to the country and its culture.

\footnotetext{
${ }^{1}$ The full text of the article could be accessed via https://www. colombotelegraph.com/index.php/full-text-of-the-banned-time-story-theface-of-buddhist-terror/
}

"[Muslims] are breeding so fast, and they are stealing our women, raping them ... They would like to occupy our country, but I won't let them. We must keep Myanmar Buddhist," the writer quoted him as telling her.

Such views of Wirathu and his Ma Ba Tha (Organisation for the Protection of Race and Religion) movement are very common in the international media. He is been blamed for much of the violence perpetrated by the military against the Muslims. He is seen as the mobilizing factor for such violence. When Beech asked him about how Buddhist teaching fit in with his ideas on Muslims, she quoted him as saying: "In Buddhism, we are not allowed to go on the offensive, (but) we have every right to protect and defend our community."

After Ma Ba Tha was banned in 2017, it was reincarnated via the Buddha DhammaParahita National Foundation vowing to protect Buddhism in the country - which they see as a citizen's right under the 2008 Constitution. I met its chairman, a soft-spoken senior monk Ashin Tilokabhivamsa at Ywana Payiyarti Monastery on the outskirts of Yangon. He argues that what Myanmar has is an immigration problem and that Islamisation is creeping into the country via the Rakhine state. When asked about the "extremist" label given to Ma Ba Tha monks, he replies: "Ours is true speech and historic facts. We never lie, we speak the truth. This hate speech is like if you show a bottle of honey and keep on saying this is poison, people will ultimately believe it and not touch it," he says, adding: "That is the western media" 2 .

Juliane Schober (2017) in her paper 'Belonging In A New Myanmar' notes that some Western media outlets have stressed a resurgence of Buddhist nationalism with Burmese xenophobia citing the Time magazine cover story as an example. She points out that while concentrating on Wirathu, they have ignored the good work done in the community by monks across Myanmar, such as when Buddhist monks gave refuge to 1,400 Muslims in Lashio, in northern Shan State, to protect them from rioting mobs in 2013, or when monks dispersed attackers at

${ }^{2}$ Interview with author in Yangon, 22 December 2018. 
a madrassa outside Rangoon in the same year or in a Muslim neighborhood in Mandalay in 2014. She also stressed that efforts to strengthen communal peace - such as an interfaith youth conference held in Yangon in 2013 or Muslim community leaders in Mandalay offering meals and robes to Buddhist monks "to promote harmonious inter-communal relations receive much less attention".

Schober says that Buddhist discourse on the involvement of monks in worldly affairs is well recorded in texts and colonial histories. "In 2007, the media image projected by the Burmese sangha (monks order) to the outside world was that of a progressive force engaged in social reforms and support for human rights, challenging the power of the military junta by protesting in the streets of Yangon and elsewhere. Reports of their marches were featured daily in the media outlets of the global public sphere, creating a powerful Buddhist narrative that equated loving-kindness (metta) with democracy" she notes. Adding that the widespread devastation caused by the tropical cyclone Nargis along the coastal regions in 2008 provided another important moment for the sangha and its civil society supporters to challenge the military regime, which proved incapable of delivering humanitarian aid to people in the ravaged regions and was even unwilling to do so. "Sangha became the channel for organizing relief and reconstruction efforts," notes Schober.

Buddhists strongly believe that there are foreign forces that are trying to destabilise Myanmar to exploit its strategic location by manipulating its delicate ethnic mix. "In big cities, we don't have problems. Most problems are in border areas," explains Arthur Myint ${ }^{3}$, Registrar, Abhidhamma Propagation Association. He adds that most Rakhine people see Rohingyas as invaders, where corrupt border controls have contributed to the problem.

"The real issue is very much socio-economic," argues Toe ZawLatt ${ }^{4}$, Operations Manager of Democratic Voice of Burma (DVB). Muslims in Myanmar are

\footnotetext{
${ }^{3}$ Interview with author in Yangon, 22 December 2018.
}

${ }^{3}$ Interview with author in Yangon, 22 December 2018. largely a trading community concentrated in urban areas, and they stand out from the poor Rohingya community in the Rakhine state. Thus Latt points out, "some minority communities are very rich. Muslim shop owners and their communities are rich. It is easy to report it as a religious issue rather than analyse it as a socio-economic issue."

These are the socio-economic realities on the ground, which are blurred when the media focus on "religious" conflicts. After the discrediting of the Marxist ideology since the break up of the Soviet Union in 1989, the world's poor and marginalized communities especially in the rural areas, are increasingly turning to religion and ethnicity to mobilize the masses against social and economic injustices. Thus, it has become easier for the global corporate media to describe peoples' protest movements as "religious conflicts" rather than looking into the economic and social issues that underline these conflicts.

\section{Socio-Economics of Conflict}

No religion has a monopoly on 'violent people', nor does anyone religion have a greater propensity for violence. Rather, social conditions such as poverty and societal upheavals generate violent behaviour, regardless of religion. It is no coincidence that poorer regions and neighbourhoods suffer higher crime rates. When people find the world changing around them, they turn to their religion to make sense of things. Some look to religion as a means to preserve what they have, and religion provides a way of understanding one's place in the world and, more importantly, one's duty (Jerryson, 2017).

Rakhine State is Myanmar's least developed state, with a poverty rate of 78 percent, compared to the 37.5 percent national average, according to World Bank estimates. Widespread poverty, poor infrastructure, and a lack of employment opportunities in Rakhine have exacerbated the cleavage between Buddhists and Muslim Rohingya and at times erupted into conflict.

In 1990, the Burmese government renamed Arakan as Rakhine State, a name commonly used now, especially concerning the Rohingya issue. In the 
State, it is estimated that 59.7 percent of the 3.8 million people are Buddhist, 35.6 percent are Muslim. Islam has come to the region in the 8th century with Arab traders.

The displacement of the Rohingya began after the Arakan Rohingya Salvation Army (ARSA) attacked 30 security outposts along the border with Bangladesh on August 25, 2017, killing over a dozen Burmese police officers, and at least one Tatmadaw (Burmese Army)soldier. In response, ARSA was officially declared a terrorist organization, the first time Myanmar used such a declaration for an insurgent group.

While the Rohingya issue has been attracting global media attention, throughout 2019 Arakan Army (an Arakan nationalist group made up of mainly Buddhists) has been involved in pitched battles with Tatmadaw. In March 2019, Myanmar's Frontier news service's Ye Mon interviewed Arakan Army's (AA) deputy chief NyoTunAung in his hideout near the China border. He said they want an Arakan state within Myanmar with a high degree of autonomy (Mon, 2019). The international media has all but ignored this conflict, which is believed to be taking the lives of hundreds of people every month as the skirmishes continue.

Michael Vatikiotis (2017), Asia director of the Centre for Humanitarian Dialogue points out, as both Buddhist and Muslim communities in Rakhine State need economic assistance, the Myanmar government would need to allow humanitarian aid to filter down to both, like how aid was dispersed after Cyclone Nargis in May 2008. "This requires carefully balancing the concerns expressed by regional neighbors for the religious communities in Rakhine State - which includes Hindus as well as Buddhists and Muslims - with the task of developing the state, which is the poorest in Myanmar" he notes.

\section{Location and Geo-Politics}

Geographically, Myanmar is situated in a very important crossroad in Asia, sandwiched between the rising global powers - China and India - and thus, geopolitics and building new economic pathways also play a crucial role here. This cannot be glossed over in analyzing how the country's sensitive ethnic and religious relationships are handled and also manipulated and exploited by foreign players. Another important factor is how the media narrative is focused on individual rights, while the crux of the Myanmar problem is rooted in peoples' collective right (i.e. Buddhists) to protect one's treasured religious-cultural heritage from new threats - perceived or imagined. Western human rights narrative tends not to recognize or give importance to the rights of the majority community.

Being mindful of the new economic activities in the region, especially in and around Rakhine State is important to analysing terrorism threats and religious conflicts in the region.

South China Morning Post (SCMP) noted in September 2017, China gas invested heavily in ports, gas, and oil in the Rakhine state. Between 1988 and 2014, China invested more than US\$ 15 billion in the military-run country, mostly in mining and energy. It also provided the military regime with weapons. In April 2017, a US\$2.45 billion pipeline from Rakhine to China's Yunnan province opened, securing a key route for Beijing to import crude from the Middle East. There is also a planned US\$ 9 billion deep-sea port and economic zone in Kyaukpyu, south of the epicenter of much of the violence.

In the future, this state will be of crucial importance to China's Belt and Road Initiative (BRI). SCMP quoted foreign ministry spokesman GengShuang saying: "We think the international community should support the efforts of Myanmar in safeguarding the stability of its national development".

India is also wooing the Myanmar government to offset any advantage China may get from helping to stem this conflict with development aid on the ground. India is worried about the potential of the Rohingya community providing fodder for jihadists active in the Indian sub-continent.

\section{International Media Narrative - Rohingyas as a "Repressed" Minority}

The international media narrative is mainly focused 
on the Rohingyas considered as a "repressed" minority in the Rakhine state, being killed or chased away from their homes by Myanmar's military. That the Myanmar military is made up largely of Buddhists, and the Rohingyas are Muslims, has added a religious element to the situation.

The exodus of Rohingyas to neighbouring Bangladesh is not new, it has been going on since the 1970s and gathered steam since 2012 when hundreds of thousands of Rohingya have fled to neighbouring countries. Many of them were victims of unscrupulous people-trafficking networks and continue to face new threats from these criminal networks (CNA, 2017), and there have been many recent reports about how young Rohingya women are forced into prostitution by such networks (Iqbal, 2017).

In an interview with the BBC in April 2017 (BBC, 2017), SuuKyi said that since 2013 people have been asking her to speak out against alleged human rights violations in Rakhine state. "People say, I say nothing, simply because they want me to make a statement condemning one community or other". She argued that what her government was doing was starting a peace process that included as a priority a verification process of people who are entitled to citizenship, and also engaging in other development activity to bring about stability and harmony "because I think a lot of problems in the Rakhine State are due to the fact that resources are limited and both communities are anxious how their lives are going to pan out".

When SuuKyi finally broke her silence on the issue on 6 September 2017, she slammed the international media and human rights organisations for spreading "misinformation" on the conflict. The fact that SuuKyi came out so strongly blaming "terrorists" for "a huge iceberg of misinformation" on the violence in Rakhine State, is perhaps because she sensed national sentiments about these double standards.

The day following SuuKyi's public statement, India's Prime Minister Narendra Modi making his first official bilateral visit to neighbouring Myanmar pledged Indian support to fight cross-border Islamic terrorism. The Indian media has reported that the ARSA is a terrorist group that is trained by the Pakistani spy agency Inter Services Intelligence (ISI) to destabilise the region including India. ARSA leader Attah Ullah was born in Pakistan and raised in Saudi Arabia and they now operate on the Bangladesh-Myanmar border, out of refugee camps near Cox Bazaar (ANI, 2020).

Mizzima news - which won a 'free media pioneer" award from the International Press Institute in 2007 - reported (Mizzima News, 2017) the day before SuuKyi' statement that Indian and Bangladesh intelligence officials have disclosed they have intercepted three long duration calls between Hafiz Tohar, military wing chief of ARSA on 23 and 24 August 2017 that hold the key to why the militant group unleashed the predawn offensive against Myanmar security forces soon after. The report said that Tohar has been trained in Pakistan by Lashkar e Tayyaba and while the Bangladesh government is also worried about these terror links, a lack of intelligence sharing network between India, Bangladesh and Myanmar may have prevented the latter from getting a prior warning on the threat.

During his visit, Modi told SuuKyi that he wants to see a peaceful border between India and Myanmar (Myanmar Times, 2017) and offered Indian cooperation in the area of security. "We are partners in your concerns over the loss of lives of security forces and innocent people due to the extremist violence in Rakhine State. Our interests in the area of security are common as neighbours. It's essential that we work together to ensure the stability of our long territorial and coastal borders," Modi said during the joint media briefing with SuuKyi in Myanmar's capital Nay Pyi Taw on 6 September.

\section{Fake News and Subjective Reporting Driving Conflicts}

Changes the world over in foreign news production during the last few decades have reduced the resources available for foreign coverage and investigative reporting, often reinforcing dominant narratives of 'us versus them' rather than unearthing the 
complexity of a situation. Since the break out of communal violence in Myanmar between Rakhine Buddhists and Rohingya Muslims in 2012, stories have exhibited this reductionism (Brooten and Verbruggen, 2017).

Lack of resources for investigative reporting and distrust between foreign (i.e. Western) media and Asian governments have led to many international news networks relying on video clips and other information provided by non-government actors, often propaganda outlets for groups that claim repression and human rights violations.

Some of the reporting on Myanmar in recent years have fallen into this trap. Video clips and photos are being provided by some unnamed activist groups which are then flashed in the media across the world as "evidence" of "genocide" against the Rohingya minority in Myanmar. Any rebuttal the government would provide is dismissed as propaganda or a "what else can they say" comment. Just before she spoke on 6 September 2017, SuuKyi had spoken on the phone to Turkish President Recep Tayyip Erdogan who has been particularly critical of Myanmar's treatment of the Rohingya, dubbing it a "genocide", and she's reported to have complained about his Deputy Prime Minister Mehmet Simsek posting fake pictures of alleged genocide in Myanmar on his Twitter account calling on the international community to act. It has been shared 1,600 times and attracted more than 1,200 likes. He later retracted it and issued an apology (see below). One photograph was alleged to have been taken in Rwanda in 1994. SuuKyi said in her statement that "(such) kind of fake information which was inflicted on the deputy prime minister was simply the tip of a huge iceberg of misinformation calculated to create a lot of problems between different countries and to promote the interests of the terrorists."

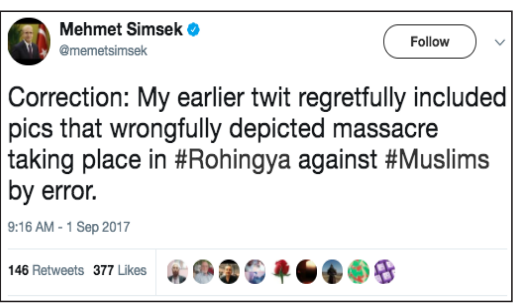

Images shared by Simsek prompted allegations on Twitter that reports of human rights abuses against Rohingya people are fake, and there were also images being shared which claimed to prove that Rohingya militants are being trained in Bangladesh (Ratcliffe, 2017).

\section{Peace Education and a Mindful Journalism Path}

A peace education path in Myanmar needs to transform the religious conflict narrative into a socio-economic development narrative. The Buddhist concept of mindfulness could be a useful strategy to use.

Let me focus on an article published in the Bangkok Post that is a good example of what mindful reporting of Asia's "conflict-driven" societies could look like. The article by Johanna Son (2018), titled "Looking for 'ASEAN Way' in Rohingya crisis" is a good piece of mindful reporting on the Rohingya issue in Myanmar. This is a far cry from the Buddhist-bashing, hectoring style of journalism from the Western media, you usually find in the global as well as regional media.

A Filipino journalist, Son is mindful of the fact that the hectoring type of journalism (as done by the international media) has led to anti-foreign sentiments and xenophobia building up in the country and that is not conducive to finding a solution to a serious socio-economic and political crisis. She also points out that it will push Myanmar into instability at a crucial time of nation-building.

Her article reflects the 'critically appreciative' style of journalism promoted by the late Sri Lankan journalist and founder of the Asian Press Union, TarzieVitachi ${ }^{5}$. A number of us who are Asian communication scholars are trying to introduce these skills into Asian journalism programs, as we believe that the Western model we teach is too adversarial and promotes conflicts rather than solving them.

Son's article reflects the values we are trying to inculcate into young Asian communicators, to be mindful and critically appreciative of the socio-

${ }^{5}$ UNTV interview in New York with Claude Robinson in 1987. The author still holds a video recording of this interview. 
economic and cultural sensitivities of the issues you cover, and contribute towards understanding the complexities and nuances of working out a solution. Her article does not talk about a Buddhist-Muslim conflict but looks at the deeper issues, which underline peoples' concerns from all sides.

She refers to the legitimate concerns of Myanmar people about the involvement of foreign-born fighters in the Arakan Rohingya Salvation Army, which attacked police posts in Myanmar's western Rakhine state in 2017. She acknowledges the "massive military response" and the refugee crisis created.

The article points out the socio-economic problems of Rakhine state where 78 percent of the people (Rohingyas as well as Buddhists) live in poverty, and how ASEAN has facilitated study tours to Indonesia for both Rakhine (Buddhists) and Rohingya (Muslim) leaders to see how multi-cultural and multi-racial issues are tackled there. It also talks about how (Muslim-majority) Indonesia is working with (Buddhist-majority) Myanmar in building hospitals and schools to help alleviate poverty in the region. While there is a reference to indifferences to refugees and some criticism of ASEAN policy, yet, the article looks for solutions through cooperation rather than waving the lightning rod of religious conflict.

It is a welcome sign that the article does not use words such as "war crimes", "crimes against humanity" and "genocide" - words that are adopted by the international media and their human rights NGOs hypocritically. The article also points out that it will take years to resolve the problem and most Rohingyas may never return to Myanmar as part of a deal. The issue of statelessness and a lack of refugee policy in ASEAN are also touched upon.

The complex issues raised in the article reflect the journalist's deeper understanding of the region and the nuances of its political dealings. The subtle message in the article is that this is a political issue with national security implications, and it is not necessarily a religious issue - or it should not be treated as merely a religious conflict and hold one party responsible for it.
More articles like these are needed in the Asian media, to wean us away from the adversarial tradition of Western journalism that often focuses on ethnic or religious differences and creates conflicts rather than helping to solve them. Reporting needs to be focused on showing that major socio-economic changes happening in the region could be done in an orderly and peaceful manner. Asian media needs encouragement to get into this practice of mindful journalism and contribute to encouraging cooperation and resolving problems without creating social chaos.

\section{REFERENCES}

AFP. 2017. How Chinese cash shores up Myanmar's Rakhine state, despite international condemnation of Rohingya crisis, 28 Sept, SCMP - retrievable from http://www.scmp. com/news/asia/southeast-asia/article/2113259/howchinese-cash-shores-myanmars-rakhine-state-despite Accessed on 25 April 2021

Al Jazeera. 2017. Myanmar: Major ethnic groups and where they live, Al Jazeera, Qatar - retrievable from https:// www.aljazeera.com/news/2017/3/14/myanmar-majorethnic-groups-and-where-they-live.Accessed on 25 April 2021

ANI. 2020. Pakistan's spy body ISI active in Myanmar helps JMB in training Rohingyas, experts, 15 Aug, Indian Express - retrievable from https://www. newindianexpress.com/world/2020/aug/15/pakistansspy-body-isi-active-in-myanmar-helps-jmb-in-trainingrohingyas-expert-2183878.htmlAccessed on 25 April 2021

BBC. 2017. Myanmar: Aung San SuuKyi exclusive interview, 6 April, BBC News - retrievable from https://www. youtube.com/watch?v=MFEEmdKbqBE Accessed on 13 March 2021

Brooten, L. and Verbruggen, Y. 2017. The problems of reporting on the Rohingya crisis, East Asia Forum, Australia - retrievable from http://www.eastasiaforum. org/2017/12/16/the-problems-of-reporting-on-therohingya-crisis/ Accessed on 20 March 2018

CNA. 2017. Displaced Rohingyas at great risk of human trafficking in overwhelmed camps, 28 Sept, Channel News Asia, Singapore.

Iqbal, N. 2017. Rohingya women in Bangladesh face 'forced prostitution', 13 Nov, BBC, UK - retrievable from http:// www.bbc.com/news/world-asia-41928555Accessed on 20 March 2018

Jerryson, M. 2017. Monks with guns, 26 April, Aeon, Australia - retrieve from https://aeon.co/essays/buddhism-can-beas-violent-as-any-other-religion. Accessed on 25 April 2021. 
Mizzima News 2017. Pakistan, ISIS allegedly behind Rakhine imbroglio, Mizzima news exclusive, 5 Sept, Myanmar.

Mon, Ye. 2019. The Arakan Arms and the 'storm of the revolution', 29 March, Frontier, Myanmar.

Myanmar Times 2017. India wants peaceful border with Myanmar, 7 Sept, Myanmar Times, Yangon - retrievable from https://www.mmtimes.com/news/india-wantspeaceful-border-myanmar.html. Accessed on 25 April 2021.

Ractcliff, R. 2017. Fake news images add fuel to fire in Myanmar, after more than 400 dead, 6 Sept, Guardian, London - retrievable from https://www.theguardian.com/ global-development/2017/sep/05/fake-news-imagesadd-fuel-to-fire-in-myanmar-after-more-than-400deathsAccessed on 20 March 2018

Schober, J. 2017. Belonging in a New Myanmar: Identity, law, and gender in the anthropology of contemporary Buddhism, Arizone State University, USA - retrievable from https://asu.pure.elsevier.com/en/publications/ belonging-in-a-new-myanmar-identity-law-and-genderin-the-anthropAccessed on 20 March 2018
Seneviratne, K. 2019. Myanmar Buddhists Say International Media Is 'Unfair', 9 January, IDN In-Depth News, Yangon - retrievable from https://www.indepthnews. net/index.php/the-world/asia-pacific/2422-myanmarbuddhists-say-international-media-is-unfair. Accessed on 25 April 2021.

Son, J. 2018. 'Looking for 'ASEAN way' in Rohingya crisis', 26 March, Bangkok Post - https://www.pressreader.com/ thailand/bangkok-post/20180326/281732680030208Acces sed on 25 April 2021

SuuKyi, Aung San. 2018. Transcript of $43^{\text {rd }}$ Singapore lecture - retrievable from https://www.iseas.edu.sg/wp-content/ uploads/2018/08/43rd-Singapore-Lecture-Speech-byAung-San-Suu-Kyi-Final-transcript.pdf. Accessed on 10 May 2019.

Vatikiotis, M. 2017. Rakhine conflict could reignite regional tension, 4 Sept, Nikkei Asian Review. 